\title{
Improvement of Minimum KIA Service Standards through Participation of Health Care Community Groups, Lumajang District
}

\author{
Farianingsih ${ }^{1}$, Sri Wahyuningsih ${ }^{2 *}$
}

${ }^{1}$ Health Office of Lumajang Regency

2University of Jember; Campus of Lumajang; sriwahyuningsih@unej.ac.id (Corresponding Author)

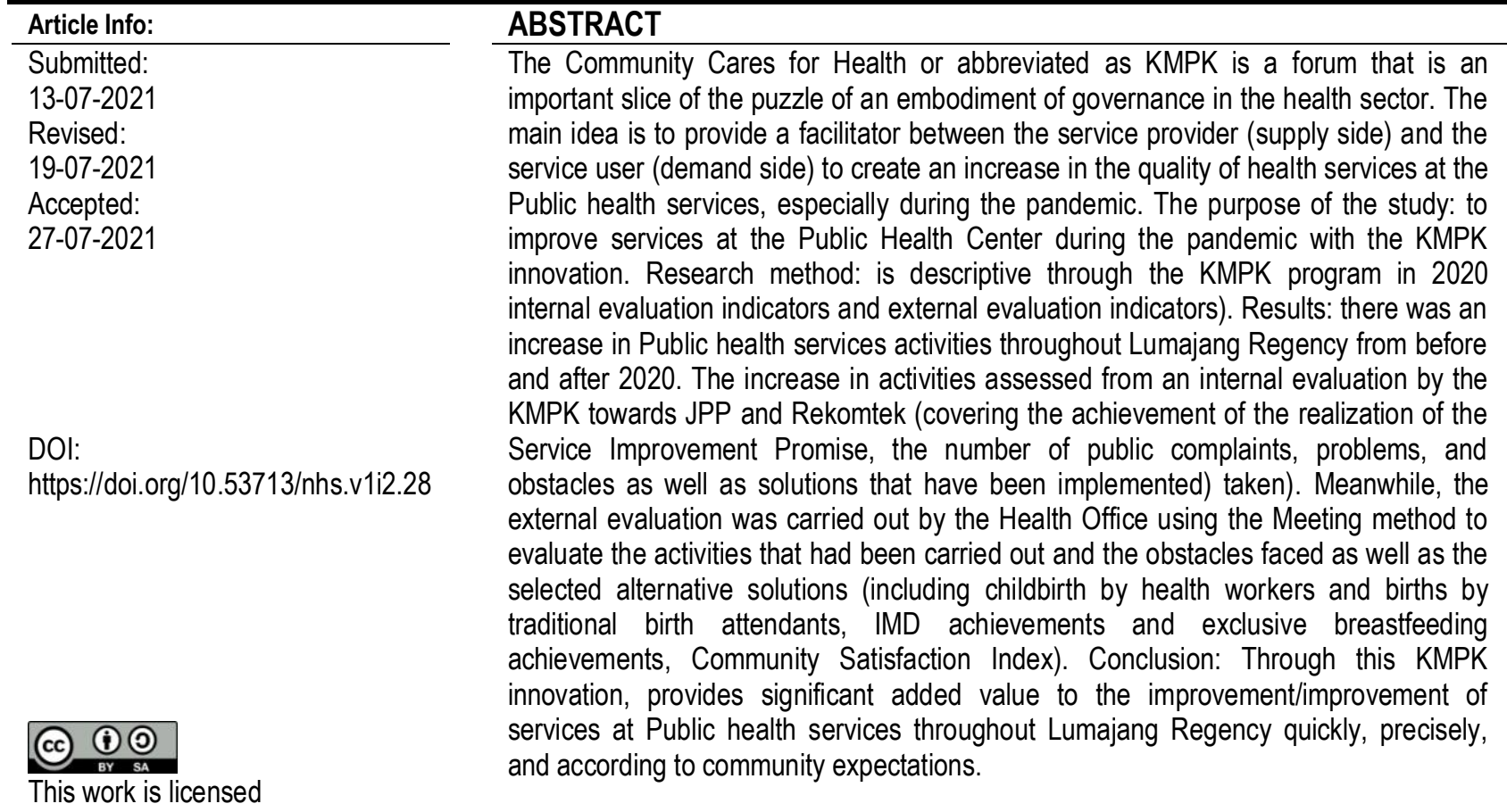

under CC BY-SA License.
Keywords: Community Health Care Community; Community Health Center

\section{INTRODUCTION}

Community Care Community Health or abbreviated KMPK in the Indonesian language is a forum that is an important slice of the puzzle of an embodiment of governance in the health sector. The main idea is to provide a facilitator between the service provider (supply side) and the service user (demand side) to create an increase in the quality of health services at the public health center. KMPK members, especially in Lumajang Regency, are multistakeholder forums consisting of elements of the Community Health Center, community leaders, cadres, religious leaders, which are then ratified by the District Head's Decree, to balance the supply and demand sides by playing an active role as a mediator, advocate, and motivator. The problems that exist in most health centers include: there are still many public complaints related to services at the Public health services (queues at the counter, facilities/infrastructure at the public health center, cleanliness, unfriendly staff, long hours, and much more), the minimum coverage of Minimum Service Standards (MSS) is still low, especially for maternity services, low coverage of exclusive breastfeeding and IMD (Early Breastfeeding Initiation). Through the implementation of the Complaint Survey conducted by the KMPK from service users at the public health center, followed up in the form of a promise to improve services by the public health center, it is hoped that it will be a link between the supply and demand sides which has an impact on improving the performance of sustainable health services and increasing MSS achievements, especially MSS for Maternal and Child Health.

The KMPK innovation started in 2015 and was initiated by the Performance Program - USAID. The replication carried out for the KMPK Innovation in Lumajang Regency is the Regional Replication carried out by the Bimtek Team in stages starting in 2016. Until now, namely 2020, the number of KMPKs that have been formed in Lumajang Regency is $21 \mathrm{KMPK}$, and everything is still going well to improve public services sustainably at the Public health services. This 
KMPK innovation has a focus on safe delivery, IMD, and exclusive breastfeeding which have a close contribution in accelerating the achievement of the SDGs (Sustainable Development Goals) target.

The purpose of the Lumajang Regency KMPK innovation is to improve services at the Public health services. Activities carried out include conducting a survey of service complaints to the public directly, followed by an analysis of the HDI (Community Complaints Index) followed up with JPP (Promise of Service Improvement) by the Public health services, and sending Rekomtek (Technical Recommendations) to the Regency Government and the Health Office. The target beneficiaries of this innovation are community health center service users in Lumajang Regency.

\section{METHOD}

This research method is descriptive through the 2020 KMPK program internal evaluation indicators (JPP public health service and Rekomtek) and external evaluation indicators (by the Health Office on activities that have been carried out and obstacles faced and alternative solutions chosen).

RESULT

Table 1. The results of the evaluation

\begin{tabular}{lcc}
\hline \multicolumn{1}{c}{ Activities } & Previous & Current Achievements of 2020 \\
\hline Realization (JPP) Public health services & $<90 \%$ & $93 \%$ to $100 \%$ \\
\hline Number of complaints & 20 to $30 /$ year & $5 /$ year \\
\hline Delivery by health workers & $98.6 \%$ & $100 \%$ \\
\hline Birth of a shaman & $2.4 \%$ & $0 \%$ \\
\hline IMD & $62 \%$ & $82.9 \%$ \\
\hline Exclusive Breastfeeding & $71.5 \%$ & $83.3 \%$ \\
\hline IKM (Community Satisfaction Index) & 2.4 to 2.99 (good) & 3 (very good) \\
\hline
\end{tabular}

Based on the table used in the evaluation there was an increase or improvement in activities from before and after the year 2020.

\section{DISCUSSION}

This improvement is supported by the KMPK program. There are 2 (two) categories of the evaluation carried out during the implementation of the KMPK program. The internal evaluation was carried out on JPP and Rekomtek Public health services throughout Lumajang Regency. The indicators used are the achievement of the realization of the Service Improvement Promise, the number of public complaints, problems, and obstacles as well as the solutions that have been taken. External evaluation by the Health Office using the meeting method to evaluate the activities that have been carried out and the obstacles faced as well as the alternative solutions are chosen. The indicators used in the external evaluation are delivery by health personnel and delivery by the traditional birth attendants, achievement of Early Breastfeeding Initiation (IMD) and achievement of exclusive breastfeeding, Community Satisfaction Index (IKM).

The 2020 pandemic period gave very significant changes to all arrangements, including of course KMPK activities, this was done to prevent the spread of covid-19 in Lumajang Regency. During the initial pandemic that occurred in 2020, activities had to stop for quite a long time. The condition of the pandemic, which is not known when it will end, provides an initiative for KMPK to be able to carry out activities.

The things that KMPK did during the Adaptation of New Habits (IMR) included: conducting outreach activities on the prevention and control of Covid-19 by paying attention to health protocols, designing a "virtual survey" using the application google form, KMPK continued to carry out activities with the implementation of adaptation of new habits so that activities continue to run by preventing and controlling Covid-19.

\section{CONCLUSION}

The KMPK innovation is a unique innovation to improve services at the Public health services and answer the problems of Minimum Service Standards (MSS) in the health sector. KMPK can bridge the community (service users) and public health service (service providers) through the implementation of a complaint survey, can raise public complaints about public health services, and can dialogue with public health services for the best solution. Through this 
KMPK initiative, it provides significant added value to the improvement/improvement of services at the Public health services quickly, accurately and according to community expectations.

\section{RECOGNITION}

The creation of this article is a form of appreciation for the innovation of the Lumajang Regency KMPK Team. Thank you to all members of the Health Care Community Group (KMPK) and Public health services throughout Lumajang Regency. Thank you, Mr. Regent and Mr. Head of the Lumajang District Health Office for the support for the innovations that have been carried out by the KMPK team.

\section{REFERENCES}

Hayati, N., \& Wahyuningsih, S. (2018). Peningkatan Pelayanan Publik Bidang Kesehatan Melalui Partisipasi Masyarakat di Kabupaten Lumajang. Proseding 1st Annual Agricultural Health Nursing Seminar. UPT Penerbitan Universitas Jember.

Keputusan Menteri Pemberdayaan Aparatur Negara No. 63/KEP/M.PAN/7/2004.

Peraturan Bupati Lumajang Nomor 50 Tahun 2017 tentang Persalinan Aman dan Peraturan Bupati Lumajang Nomor 38 Tahun 2018 tentang Perubahan Atas Peraturan Bupati Lumajang Nomor 50 Tahun 2017 tentang Persalinan Aman.

Peraturan Daerah Provinsi Jawa Timur No. 14/2016 tentang perubahan atas Perda Provinsi Jawa Timur no.8/2011 tentang pelayanan public.

Peraturan Menteri Kesehatan RI nomor 741/menkes/per/VII/2008 dan 828/menkes/SK/IX/208 tentang Standart Pelayanan Minimal Bidang Kesehatan di Kabupaten/Kota.

Peraturan Menteri Kesehatan RI nomor 828/menkes/SK/IX/2008 tentang Petunjuk Teknis Standar Pelayanan Minimal Bidang Kesehatan di Kabupaten/Kota.

Peraturan Menteri Pemberdayaan Aparatur Negara Nomor 13 Tahun 2009 tentang Pedoman Peningkatan Kualitas Pelayanan Publik Dengan Partisipasi Masyarakat.

Surat Keputusan Bupati Lumajang Nomor 188.45/175/427.12/2015 tentang Pokja MPK (Masyarakat Peduli Kesehatan).

Surat Keputusan Kepala Dinas Kesehatan Kabupaten Lumajang Nomor 800/1075/427.55/2019 tentang Tim Bimbingan Teknis Replikasi Kegiatan Pelayanan Publik di Puskesmas.

Surat Keputusan Kepala Dinas Kesehatan Kabupaten Lumajang Nomor 800/9875/427.55/2019 tentang Tim Otopsi Sosial.

Undang-undang Nomor 25 Tahun 2009 tentang Pelayanan Publik (Lembaran Negara Republik Indonesia Tahun 2009 Nomor 144, Tambahan Lembaran Negara Republik Indonesia Nomor 5038).

Undang-undang Nomor 36 Tahun 2009 tentang Kesehatan (Lembaran Negara Republik Indonesia Tahun 2009 Nomor 112, Tambahan Lembaran Negara Republik Indonesia Nomor 5063).

USAID 2014 tentang Kinerja, Modul dan panduan pengelolaan pengaduan sebagai metode efektif peningkatan kualitas pelayanan public (Pendidikan dan Kesehatan). 